\title{
ASSESSMENT OF HEAVY METALS UPTAKE BY SOME SELECTIVE BACTERIAL STRAINS ISOLATED FROM HAZARIBAGH TANNERY EFFLUENT IN DHAKA CITY, BANGLADESH: BIOSORPTION VIEWPOINT
}

\author{
Md. Monirul Islam ${ }^{*}$, Md. Liakat Hossain ${ }^{2}$, Md. Monirul Islam ${ }^{l}$, Pronabananda Das ${ }^{l}$, S.A.M. Shariar Islam ${ }^{l}$, M.T. Jahan ${ }^{l}$, M.H. Kabir ${ }^{l}$, \\ M.R. Islam ${ }^{1}$ and, A.N.K. Mamun ${ }^{1}$
}

Address (es): Md. Monirul Islam,

${ }^{1}$ Plant Biotechnology and Genetic Engineering Division, Institute of Food and Radiation Biology, Atomic Energy Research Establishment, G.P.O. Box No-3787, Dhaka1000 , Bangladesh

${ }^{2}$ Institute of Tissue Banking and Biomaterial Research, Atomic Energy Research Establishment, G.P.O. Box No-3787, Dhaka-1000, Bangladesh

*Corresponding author: monirgebcu@gmail.com

\section{ABSTRACT}

https://doi.org/10.36547/be. 370

Biosorption can be defined as a Physiochemical process that cleanses heavy metal-contaminated water and aids in environmental remediation. The present exploration was carried out to examine the metal biosorbent potentiality of five bacterial strains.Biosorption capacity was assessed using Atomic Absorption Spectrophotometer where Bacillus thuringiensis showed uptake of $\mathrm{Pb} 0.56 \mathrm{mg} / \mathrm{g}$ that was around $34.74 \%, \mathrm{Cd} 0.38 \mathrm{mg} / \mathrm{g}(20.0 \%), \mathrm{Ni} 0.30 \mathrm{mg} / \mathrm{g}(15.8 \%), \mathrm{Cr} 0.76 \mathrm{mg} / \mathrm{g}(39.58 \%), \mathrm{Cu} 0.14 \mathrm{mg} / \mathrm{g}(7.61 \%)$ and As $0.28 \mathrm{mg} / \mathrm{g}(14.43 \%)$ respectively. Micrococcus sp. showed reduction of Pb $0.62 \mathrm{mg} / \mathrm{g}(39.89 \%), \mathrm{Cd} 0.40 \mathrm{mg} / \mathrm{g}(21.10 \%), \mathrm{Ni} 0.22 \mathrm{mg} / \mathrm{g}(11.6 \%), \mathrm{Cr} 0.46 \mathrm{mg} / \mathrm{g}$ (23.96\%), Cu 0.56mg/g (30.43\%) and As $0.03 \mathrm{mg} / \mathrm{g}(1.75 \%)$ respectively whereas Pseudomonas sp. exhibited reduction of As $0.56 \mathrm{mg} / \mathrm{g}$ and $0.20 \mathrm{mg} / \mathrm{g}$ (16\% and $10 \%)$, $\mathrm{Cu} 0.26 \mathrm{mg} / \mathrm{g}$ and $0.46 \mathrm{mg} / \mathrm{g}$ (14\% and 25\%), Cr $0.74 \mathrm{mg} / \mathrm{g}$ and $0.56 \mathrm{mg} / \mathrm{g}$ (39\% and $29 \%), \mathrm{Ni} 0.12 \mathrm{mg} / \mathrm{g}$ and $0.38 \mathrm{mg} / \mathrm{g}(6 \%$ and $20 \%), \mathrm{Pb} 0.26 \mathrm{mg} / \mathrm{g}$ and $0.68 \mathrm{mg} / \mathrm{g}(19 \%$ and $41 \%$ ) and $\mathrm{Cd} 0.46 \mathrm{mg} / \mathrm{g}$ and $0.64 \mathrm{mg} / \mathrm{g}(24 \%$ and $34 \%$ ) respectively. The result displayed that the highest degradation of $\mathrm{Pb}$ and $\mathrm{Cr}$ were shown by Pseudomonas aeruginosa $(41 \pm 0.01 \%)$ and Bacillus thuringiensis $(39.58 \pm 0.05 \%)$ and lowest degradation of As was shown by Micrococcus sp. that was around $1.75 \pm 0.001 \%$. By contrast, degradation of $\mathrm{Pb}$ in moderate condition was witnessed by Bacillus cereus (19.89 $\pm 0.01 \%)$ and $\mathrm{Ni}$ by Bacillus thuringiensis $(15.8 \pm 0.05 \%)$ respectively. Heavy metal's biosorption is a quick process that might be an advantageous side for the removal of vast range of pollutants.

Keywords: Biosorption, Heavy metals, Bacillus thuringiensis, Micrococcus sp. Pseudomonas sp. Degradation

\section{INTRODUCTION}

Leather is one of the popular industries of Bangladesh which plays a pivotal role in the country's economy, as well as having a good international reputation. In the fiscal year 2016-2017, the leather sector contributed \$1.39 billion to Bangladesh's economy, accounting for 4\% of GDP (Hoppe et al., 2009). Bangladesh has about 113 tanneries that produce about one hundred and eighty million square feet of skins and hides annually. Notably, over 2500 smaller footwear manufacturers are engaged in making high-quality footwear from about 30 modern shoe manufacturing plants. Approximately 5058000 people perform their job in this sector. Most of the tanneries generate $20000 \mathrm{~m}^{3}$ tannery effluent and 232 tonnes of solid waste every day due to the lack of proper effluent plants. Though tannery has a potential value but liquid and solid wastes are potential contaminants (Paul, 2013).

Industrial effluent, which is heavily loaded with heavy metals, brings about health damage to animals, aquatic life, plants, and humans putting stress on the fauna as well as flora (Robin et al., 2012). Li et al., (2010) reported the response of food crops to salinity stress in affecting the extent of heavy metal adulteration and changing their physiological and biochemical properties. Tannery effluent gets highly polluted because of the existence of conductivity, imbalance suspended solids, nitrogen, chromium, copper, cadmium, manganese, sulfate and sulfide, and chemical oxygen demand (COD) and biological oxygen demand (BOD) biological oxygen demand (BOD), and chemical oxygen demand (COD) (Zahid et al., 2006; Mondal et al., 2005). Tannery effluents discharged into aquatic systems and toxic metals associated; possess different environmental and public health concerns. Approximately 2 million people those are residing adjacent to the Buriganga River and Hazaribagh are somehow facing trouble by the waste of tannery (AriasBarreiro et al., 2010).

Industrial wastewater, which is the source of various genres of organic and inorganic contaminants, is thrown away in receiving water compartments. These heavy metals, which are biologically non-biodegradable, play role in polluting the environment especially in high concentrations as well as their persistency in wastewater treatment, and their toxicity has become a global concern (Jern, 2006). For this reason, it is necessary to find out an eco-friendly solution to make the environment clean from metal contamination and therefore to improve the health progressively of the polluting environment (Sekhar et al., 2004). Therefore, the study focused on the Hazaribagh tannery that dropped away untreated tannery effluents including bio-toxic substances that cause serious health as well environmental issues in our community (Igiri et al., 2018; Gain et al., 2002). Hazaribagh is the principal leather processing zone which is located in the southern part of Dhaka city. The random and mismanaged proliferation of Bangladesh's leather manufacturing company has had a detrimental impact on the surrounding environment, particularly land and water, posing a public health risk (Alam et al., 2019).

The tannery wastewaters containing high organic substances turn into a dark brown that differs according to the high presence of chemicals (Kongjao et al., 2008). The metal ion is concentrated through microorganisms by binding process (Joutey et al., 2015). The binding capacity of metal ions with protein and the prevention of DNA replication and the following cell division cause toxicity (Kar $\boldsymbol{e t}$ al., 1992). Toxic metal pollutants of concern include arsenic, silver, chromium, selenium, nickel, zinc, uranium, cadmium, lead, gold, and mercury (Ahalya et al., 2003). Heavy metals enter into the food chain and ultimately in the human body, and lead to cause various life-threatening diseases and disorders (Lee $\boldsymbol{e t}$ al., 2007). Various microorganisms have been originated to improve the process of detoxification to combat the negative impact of inorganic metals (Igiri et al., 2018). The harmful effects on humans and animals are the result of Heavy metal accumulation that affects the biota of the riverine ecosystem and microbiological balance of soils that reduce fertility (Malik and Maurya, 2014; Barbieri, 2016). Metal poisoning is responsible for causing disease symptoms like dementia in adults, mental disturbance in children, liver and renal diseases, and nervous system disorders (Flora et al., 2008; Jan et al., 2011).

Different conventional physicochemical methods used in remediation offer disadvantages like uneconomical, high reagent and energy requirement, and production of a huge amount of chemical waste, delayed metal precipitation, and unfinished removal(Ahalya, 2003; Ayangbenro and Babalola, 2017; Aziz et al., 2015). Bioremediation through the use of microbes has received considerable interest and great attention over the years because it is a more cost-effective and eco-friendly method and efficient alternative approach to reduce or eliminate toxic heavy metals to safeguard the ecosystem compared with convention methods (Igiri et al., 2018; Aryal et al., 2015). Recently, Gadd (2000) stated the important application of microorganisms at high priority in the recovery of heavy metals from industrial effluents. Volesky and Holan (1995) decipher the fundamental mechanism of the biosorption process which is composed of three steps such as cell surface binding, extracellular participation, and intracellular bioaccumulation. Biotechnology possesses a significant advantage for the removal of heavy metals by entrapping metal ions, mainly through the process of biosorption using the capability of diverse bacteria and other microorganisms (Lesmana et al., 2009). The biosorption methods have been more popular than the conventional methods due to the affordability of biosorbent and it provides various benefits of metal recuperation as well as the regeneration of biomass (Volesky, 2007). In this 
regard, the current study has investigated the potentiality of bacterial biomass as a biosorbent for the removal of heavy metals from environmental pollutants.

\section{MATERIALS AND METHODS}

The experiments were carried out in Soil and Environment Laboratory, Biological Research Division, Bangladesh Council of Scientific and Industrial Research (BCSIR), Dhaka-1205, Bangladesh.

\section{Microbial strains}

In the current study, five microbial species were employed: Bacillus thuringiensis $(\mathrm{Bt}), \quad$ Bacillus cereus $(\mathrm{Bc}), \quad$ Pseudomonas monteilii $(\mathrm{Pm})$, Pseudomonas aeruginosa $(\mathrm{Pa})$, and Micrococcus luteus $(\mathrm{Ml})$. All of the five microbes were previously isolated from tannery effluent at Soil and Environment Laboratory, Biological Research Division, Bangladesh Council of Scientific and Industrial Research.

\section{Biomass preparation}

Bacterial strains were maintained on casamino acid media (CAA), which is made up of $5 \mathrm{~g} / \mathrm{L}$ casamino acids (Oxoid); $\mathrm{K}_{2} \mathrm{HPO}_{4}$, and $0.25 \mathrm{~g} / \mathrm{L} \mathrm{MgSO}$. The optimum growth was determined by adjusting pH 5.5 (Hussein et al., 2004). The specific weight of each bacterial cell was harvested by performing a centrifugation process at room temperature for 15 minutes, which was afterward washed two times using then washed twice with autoclaved double distilled water. In deionized water, the cells were ultimately suspended to obtain a final concentration of $5 \mathrm{~g} / \mathrm{L}$.

\section{Bacterial growth rate determination}

The cell suspension's optical density was measured at the wavelength of $620 \mathrm{~nm}$ at different time intervals $(0,6,12,24,30,36,48$, and 60 hours) to assess the bacterial growth rate using a spectrophotometer.

\section{Metal Solutions}

Different concentration of metals was made by dissolving Cadmium Nitrate, Chromium (III) Nitrate, Nickel Nitrate, Cupric Sulphate, Lead (II) Nitrate, and Sodium Meta Arsenatesalts in deionized water to get a final concentration of $100 \mu \mathrm{g} / \mathrm{mL}$. All the glassware was washed by using $0.1 \mathrm{M} \mathrm{HCl}$, so that metal elements cannot bind with them.

\section{Metal biosorption by different isolates}

Heavy metal biosorption tests were performed in an Erlenmeyer flask having 100 $\mathrm{ml}$ of each sample with $10 \pm 1.0 \mathrm{mg}$ of cells. The procedure of the current experiment is briefly shown in figure 01 .

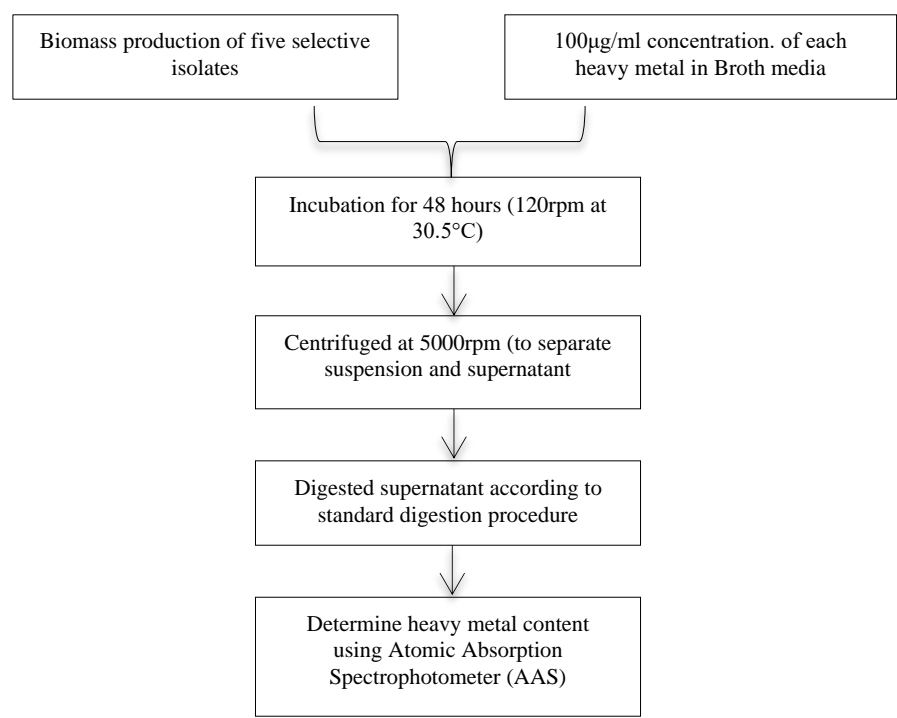

Figure 1 Flowchart showing the biosorption process for the removal of heavy metal
Cells, as well as waste, were kept under incubation for 48 hours without any interruption in agitation which was maintained at $120 \mathrm{rpm}$, at $30.5^{\circ} \mathrm{C}$ to reach equilibrium. Cells were obtained via culture and procured from the same flask at the same growth phase in all assays. After 48 hours, cells were centrifuged at 5000 $\mathrm{rpm}$ to separate suspension and supernatant from the medium. Supernatants were digested according to standard digestion procedure and Atomic Absorption Spectrophotometer (AAS) was used to determine residual heavy metal concentration. To ensure proper bacterial growth in the batch culture, optimum temperature and $\mathrm{pH}$ were maintained accurately (Hietala and Roane, 2009).

\section{Measurement of metal uptake}

In the biosorption of the tested metals by the diverse bacterial strains, most of the metal ions were cloistered very fast from solutions within the first 15 minutes and almost no increase in the level of bounds metals have occurred after this time interval. The differentiation of the sorption execution of the different biosorbent was achieved under the same environmental conditions (i. e. $\mathrm{pH}$, temperature and agitating speed, etc).

The formula used for the calculation of the amount of heavy metal bound is shown below.

$\mathrm{Q}=\frac{V(L) x(C i-C f)\left(\frac{m g}{L}\right)}{S(g)}$

Where $\mathrm{Q}$ is equal to $\mathrm{mg}$ of metal uptake of biomass per gram, $\mathrm{S}$ represents the mass of added cells on a dry basis ( $\mathrm{g}$ ), Ci symbolizes the initial conc., of metal in the solution $(\mathrm{mg} / \mathrm{l})$, Cf denotes final metal conc., in the solution $(\mathrm{mg} / \mathrm{l})$, and $\mathrm{V}$ represents the metal solution volume in $\mathrm{ml}$.

\section{Statistical Analyses}

The data were analyzed statistically using a one-way analysis of variance (ANOVA) with a $\mathrm{p}=0.05$ significance level. The data was processed into the Microsoft Excel 2010 software, which was used to compute the means and standard deviation.

\section{RESULTS}

Recent research activities have suggested microorganisms could be a good choice to rectify the contamination of metals by removing metals from contaminated waste materials, Recent studies have indicated that microbes might be used to rectify metal contamination by removing metals from contaminated waste, solubilizing metals or sediments, and sequestering metals in soils to assist in their extraction. The growth pattern of five different isolates was observed in nutrient broth media supplemented with 100ppm of total 06 individual heavy metals $(\mathrm{Pb}$, $\mathrm{Cr}, \mathrm{Cu}, \mathrm{Cd}, \mathrm{Ni}, \mathrm{As}$ ) at different time intervals, as is depicted in fig 2(a), 3(a), 4(a), 5 (a), 6(a), 7(a). The growth of the organism gets decreased after exceeding 48 hours of incubation.

As is observed in fig 2(b), 2(c), 2(d), the lowest concentration of Pb content was recorded by Pa which was preceded by MI. Pa and MI contributed to the fast and maximum removal of $\mathrm{Pb}$ content. The order of uptake $\mathrm{Pb}$ content is as follows: $\mathrm{Pa}>\mathrm{MI}>\mathrm{Bt}$. The maximum amount of $\mathrm{Pb}$ uptake was occurred by $\mathrm{Pa}$. After 48 hours incubation of five isolates in media augmented with $100 \mathrm{ppm}$ of $\mathrm{Cr}$, it was seen in fig. 3(b) that the lowest concentration of $\mathrm{Cr}$ was observed by $\mathrm{Bt}$ which is preceded by $\mathrm{Pm}$. So, the maximum percent of $\mathrm{Cr}$ removal as well as maximum uptake of $\mathrm{Cr}$ was recorded by Bt and Pm respectively (Fig 3(c) and Fig. 3(d)). The order of $\mathrm{Cr}$ uptake was as follows: $\mathrm{Bt}>\mathrm{Pm}>\mathrm{Bc}>\mathrm{Pa}>\mathrm{MI}$

$\mathrm{Cu}$ absorption potentiality was also observed for all selected isolates. As depicted in fig 4(b), the minimum concentration of $\mathrm{Cu}$ content in the solution was recorded by MI, and the highest percentage of $\mathrm{Cu}$ removal was achieved by MI isolate (Fig 4 (c)). In fig 4(d), the lowest uptake of $\mathrm{Cu}$ content was found in $\mathrm{Bt}$ whereas the highest percent of $\mathrm{Cu}$ uptake was occurred by MI. The order of $\mathrm{Cu}$ uptake was as follows: $\mathrm{MI}>\mathrm{Bc}>\mathrm{Pa}>\mathrm{Pm}>\mathrm{Bt}$.

Figure 5(a) represents the growth pattern of selected isolates in media supplemented with 100ppm of $\mathrm{Cd}$. The lowest concentration of $\mathrm{Cd}$ was observed by $\mathrm{Pa}$ after 48 hours of incubation of five isolates. So, the maximum percent of $\mathrm{Cd}$ removal as well as maximum uptake of $\mathrm{Cd}$ content was obtained by $\mathrm{Pa}$ which was followed by $\mathrm{Pm}$ isolate. The order of $\mathrm{Cd}$ uptake by bacterial isolates was as follows: $\mathrm{Pa}>\mathrm{Pm}>\mathrm{MI}>\mathrm{Bt}>\mathrm{Bc}$.

Furthermore, after adding 100ppm Ni in nutrient broth media, all isolates had been examined for Ni concentration after 48 hours of incubation. As is observed in fig 6(b), the highest Ni content was recorded in solution inoculated with Pm, whereas, 
the lowest Ni content was observed by Bacillus cereus. Among five isolates, Bacillus cereus exhibited not only the highest percentage of Ni removal but also the maximum uptake of Ni content (Fig 6(c) and Fig 6(d)). Each isolate's order of uptake potentiality is as follows: $\mathrm{Bc}>\mathrm{Pa}>\mathrm{Bt}>\mathrm{MI}>\mathrm{Pm}$.

In our current study, to determine the absorption efficacy of isolates, As (Arsenic) content was estimated in $\mathrm{mg} / \mathrm{ml}$ after 48 hours incubation of those isolates in a solution containing 100ppm As (Fig 7(b)). As content had shown lowest in solution with $\mathrm{Pm}$ isolate; thus contributing to the maximum percent of As removal (Fig 7(c)). Furthermore, according to Fig. 7(d), the efficacy of As uptake can be ordered as follows: $\mathrm{Pm}>\mathrm{Bt}>\mathrm{Pa}>\mathrm{Bc}>\mathrm{MI}$

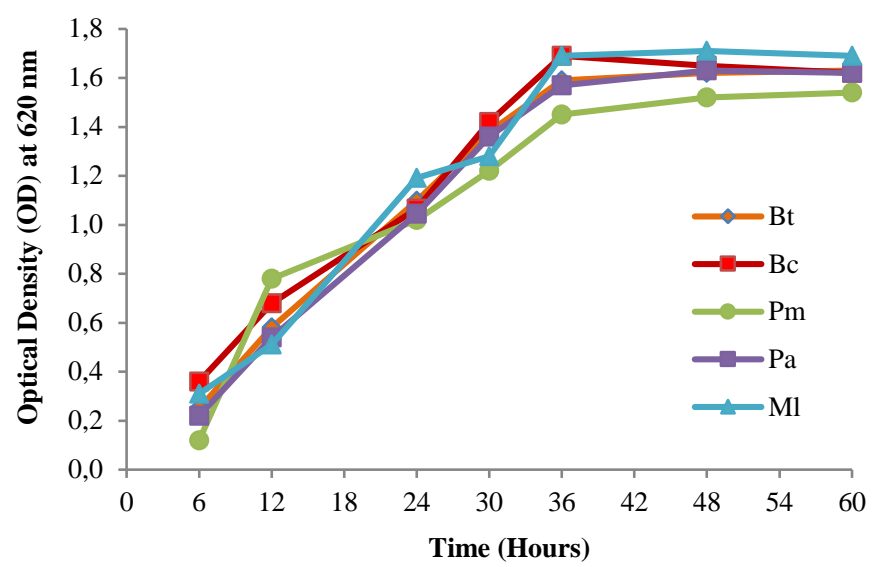

Figure 2 (a): Growth pattern of 05 selective isolates in nutrient broth media with $100 \mathrm{ppm} \mathrm{Pb}$

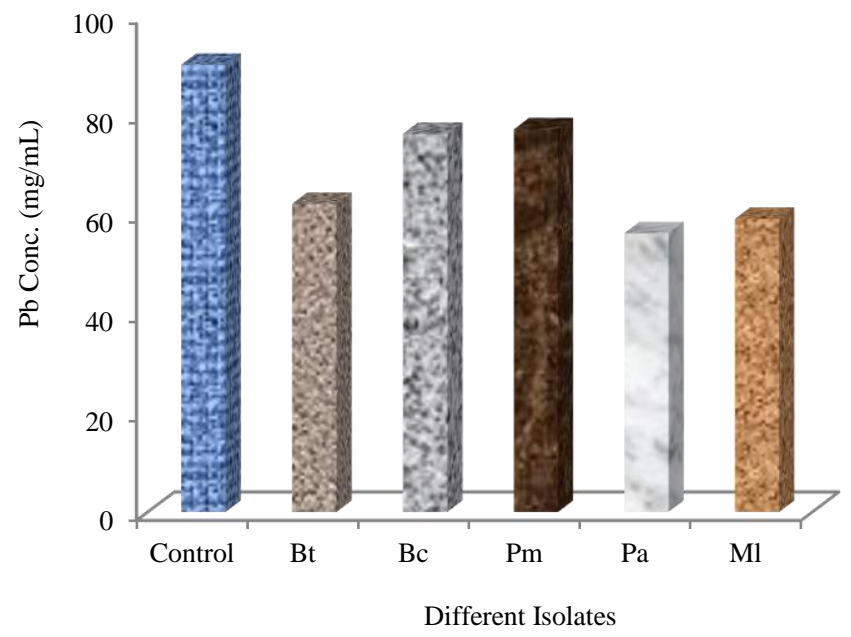

Figure 2 (b): Pb content after 48 hours' incubation by different isolates

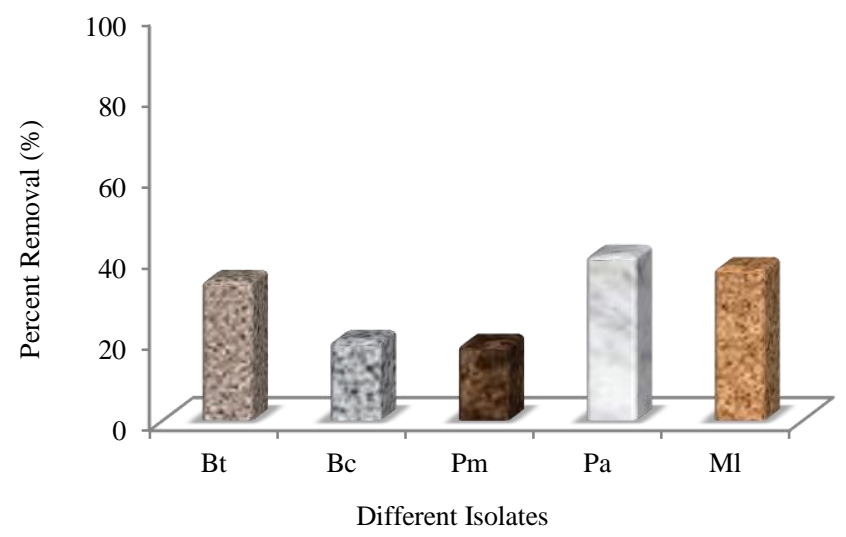

Figure 2 (c): Percent Removal of $\mathrm{Pb}$ content by each bacterial isolates

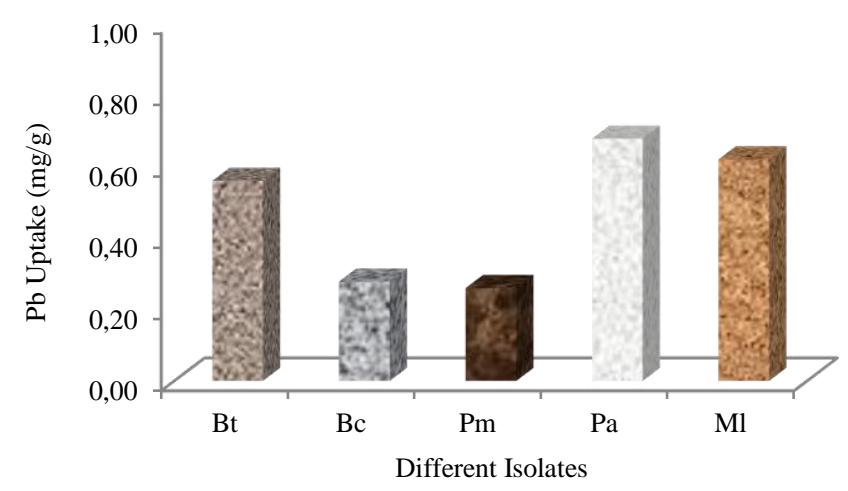

Figure 2 (d):Uptake of $\mathrm{Pb}$ content by each bacterial isolates

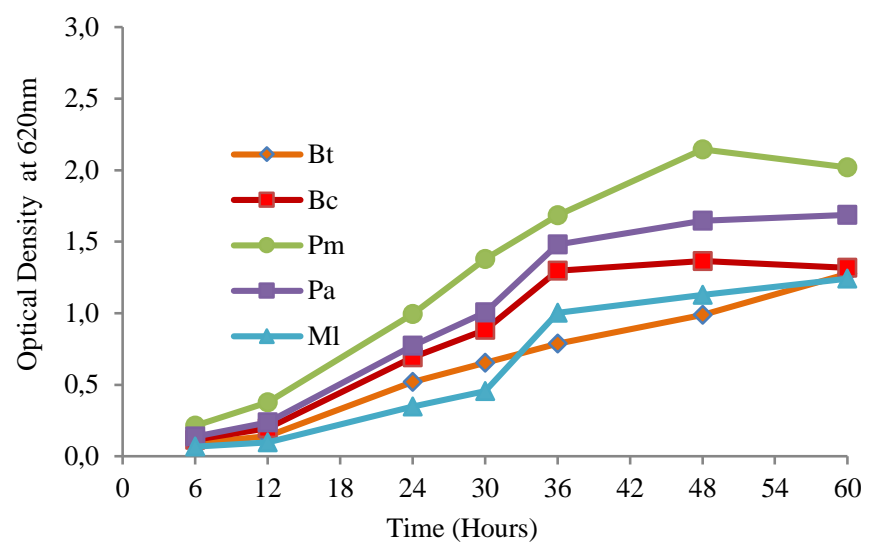

Figure 3 (a): Growth pattern of 05 selective Isolates in nutrient broth media with $100 \mathrm{ppm}$ of $\mathrm{Cr}$

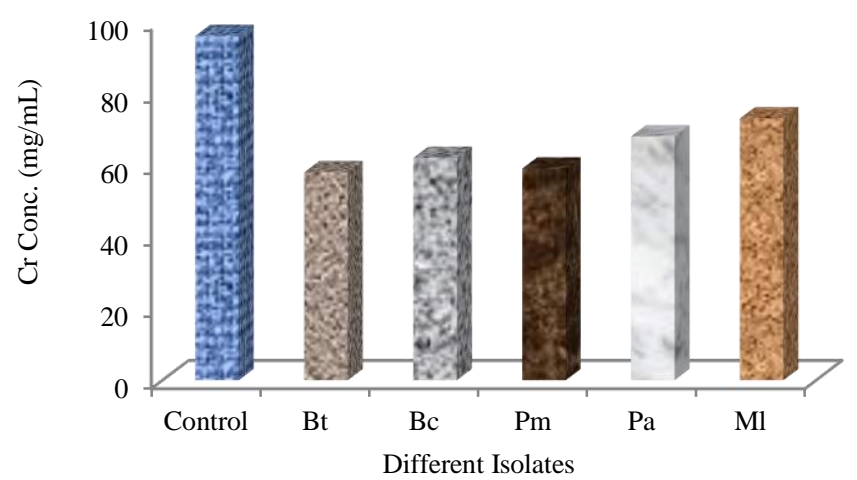

Figure 3 (b): Cr content after 48 hours incubation by different isolates

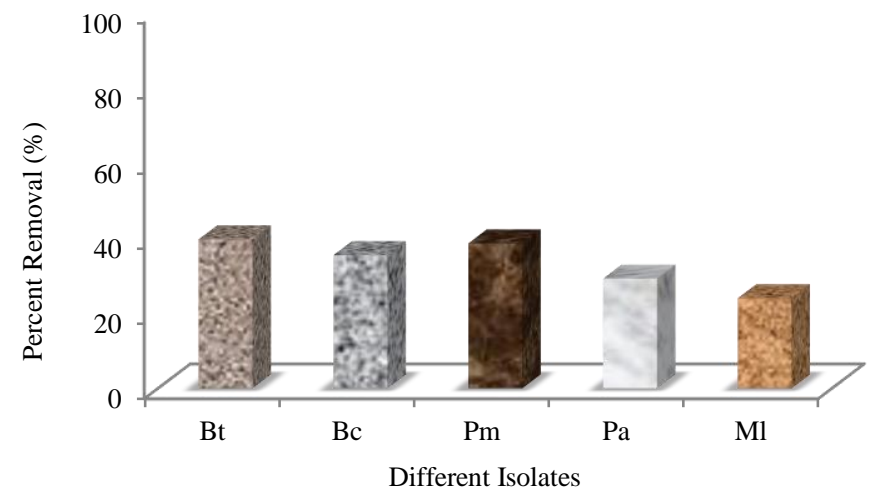

Figure 3 (c): Percent Removal of $\mathrm{Cr}$ content by each bacterial isolates 


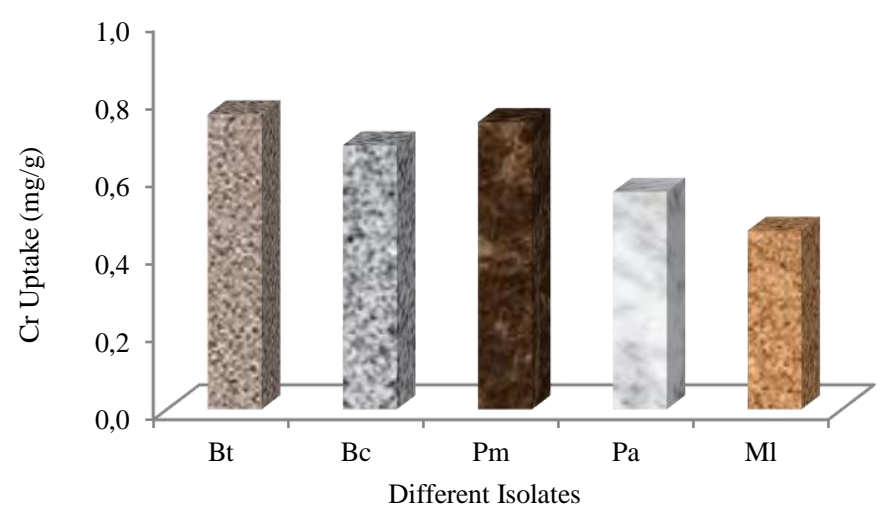

Figure 3 (d): Uptake of $\mathrm{Cr}$ content by each bacterial isolates

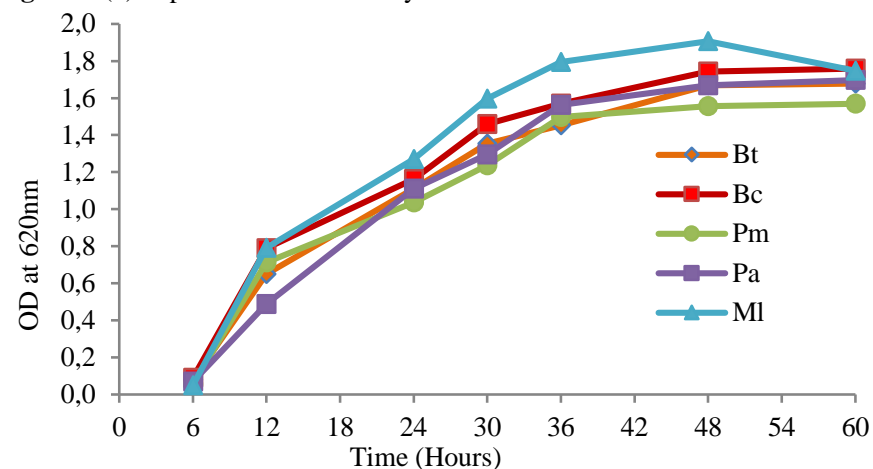

Figure 4 (a): Growth pattern of 05 selective Isolates in nutrient broth media with $100 \mathrm{ppm}$ of $\mathrm{Cu}$.

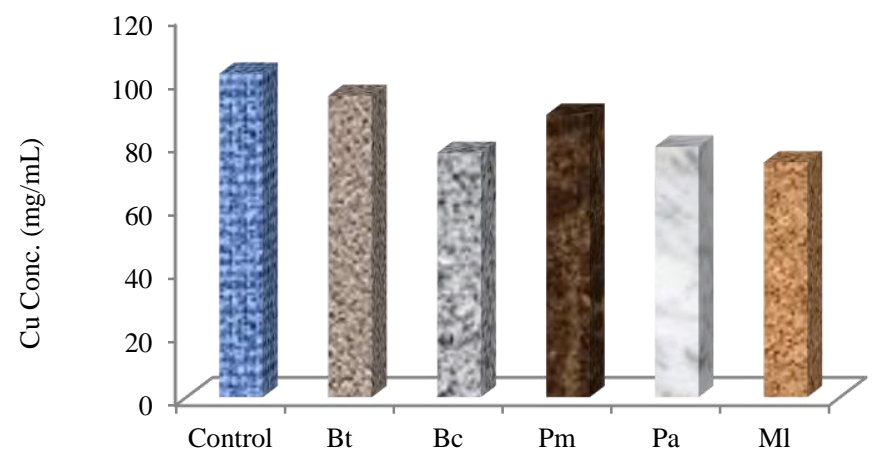

Different Isolates

Figure 4 (b): Cu content after 48 hours incubation by different isolates

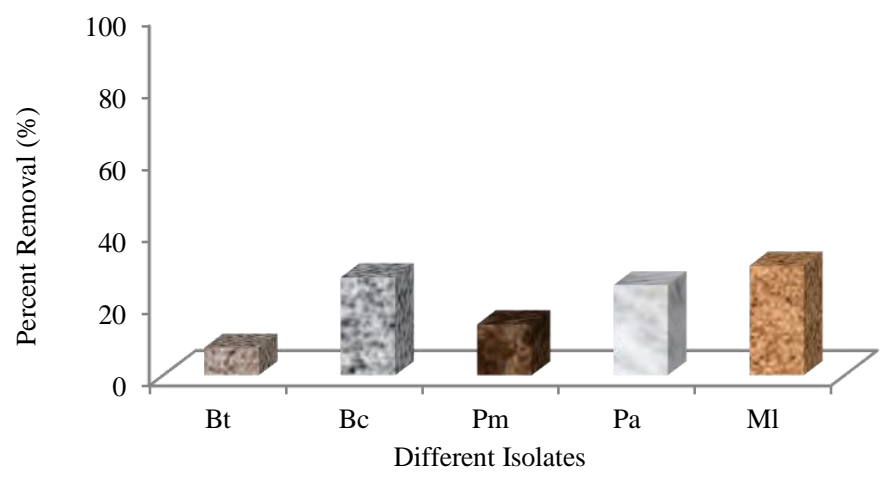

Figure 4 (c): Percent Removal of $\mathrm{Cu}$ content by each bacterial isolates

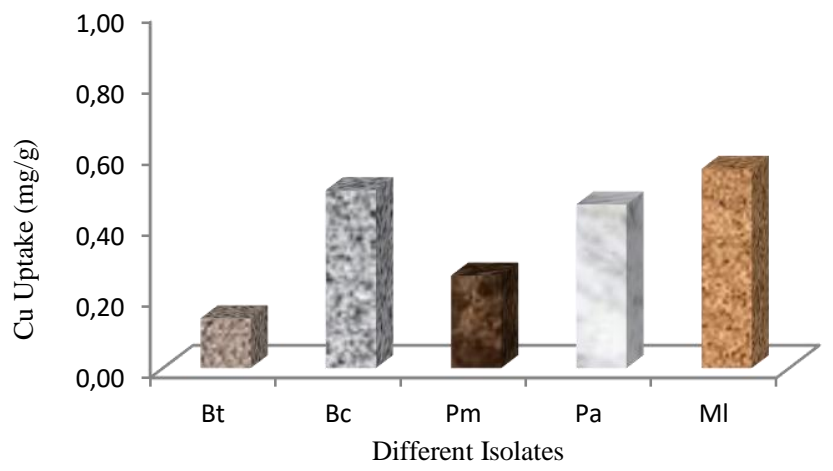

Figure 4 (d): Uptake of $\mathrm{Cu}$ content by each bacterial isolates

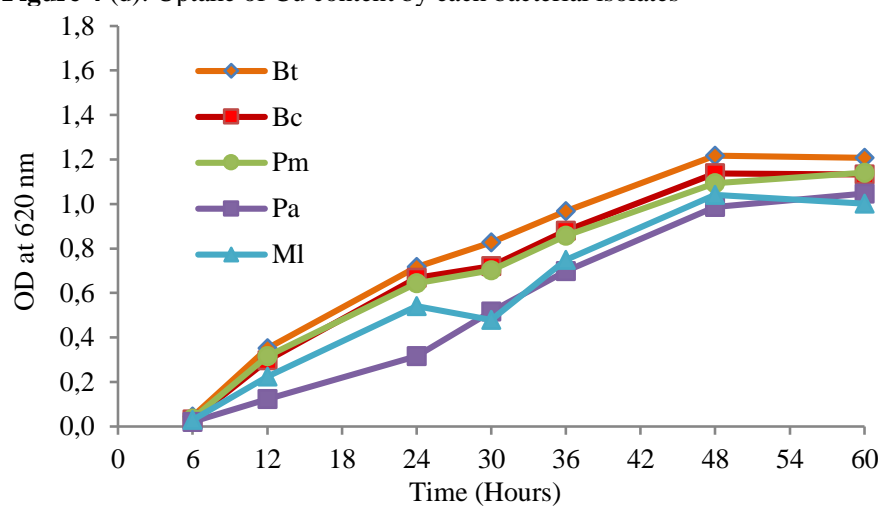

Figure 5 (a): Growth pattern of 05 selective Isolates in nutrient broth media with $100 \mathrm{ppm}$ of $\mathrm{Cd}$.

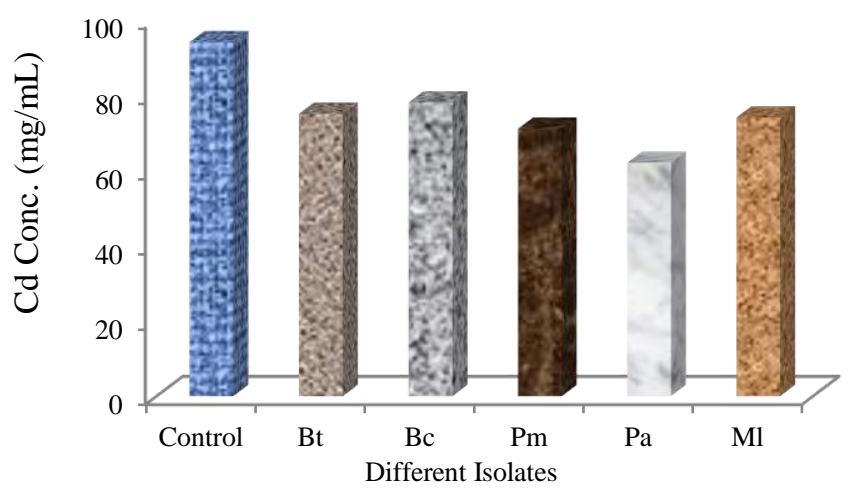

Figure 5 (b): Cd content after 48 hours incubation by different isolates

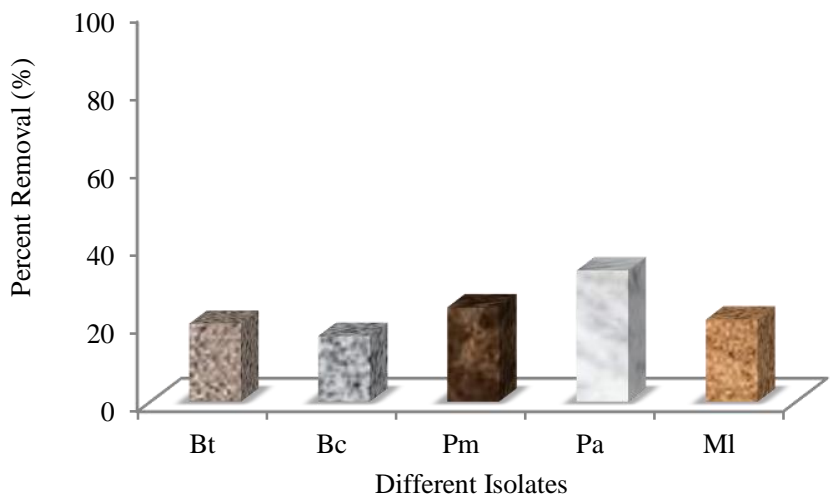

Figure 5 (c): Percent Removal of Cd content by each bacterial isolates 


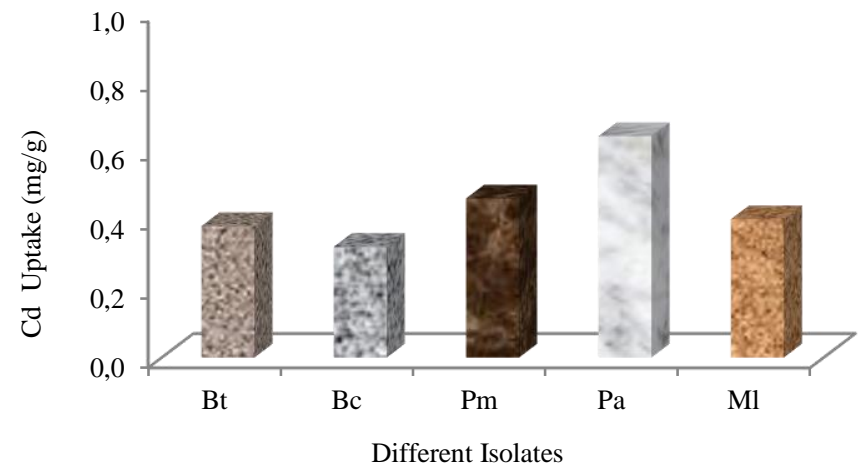

Figure 5 (d): Uptake of Cd content by each bacterial isolates

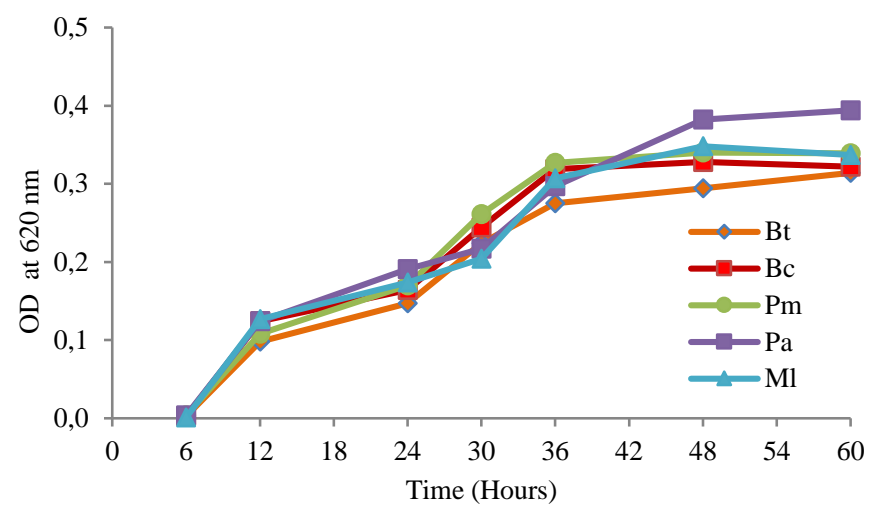

Figure 6 (a): Growth pattern of 05 selective Isolates in nutrient broth media with $100 \mathrm{ppm}$ of Ni.

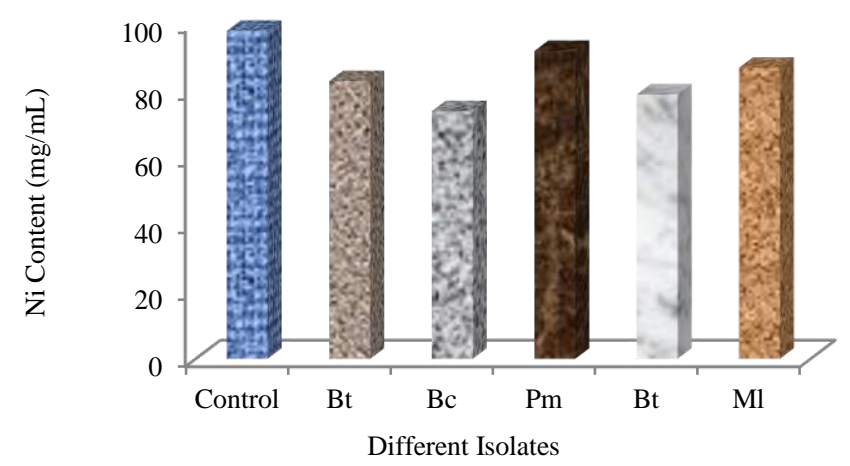

Figure 6 (b): Ni content after 48 hours incubation by different isolates

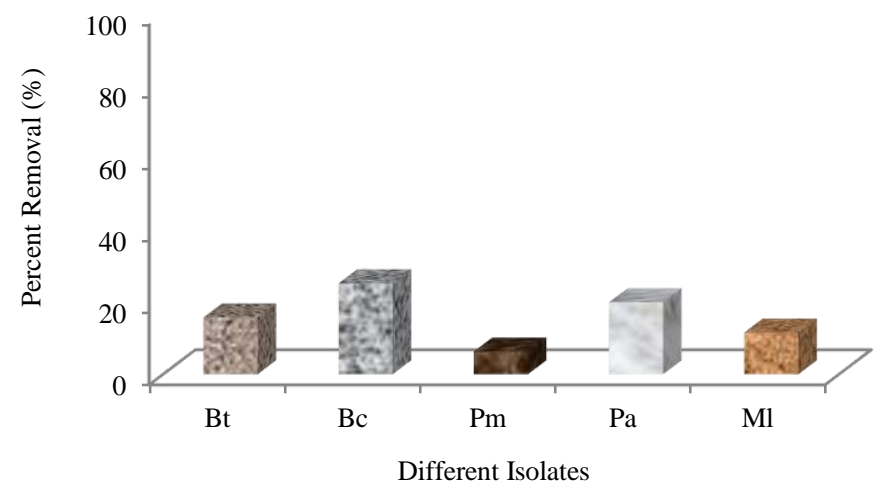

Figure 6 (c): Percent Removal of Ni content by each bacterial isolates

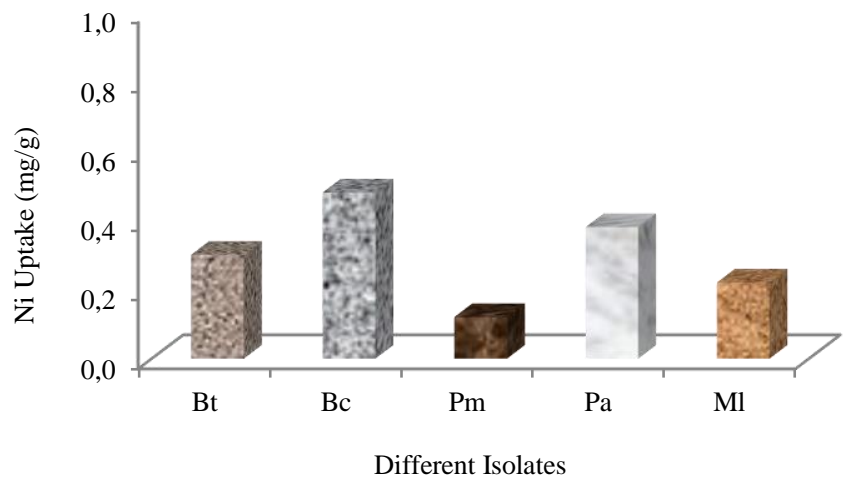

Figure 6 (d): Uptake of Ni content by each bacterial isolates

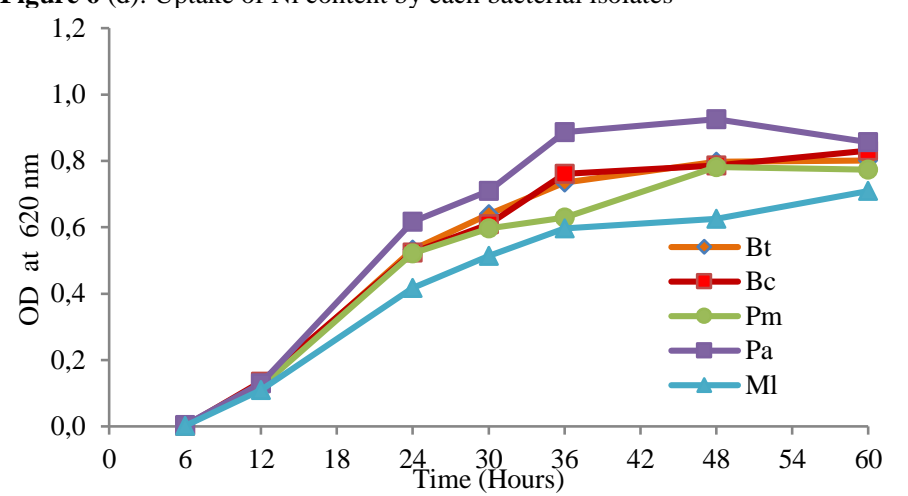

Figure 7 (a): Growth pattern of 05 selective Isolates in nutrient broth media with $100 \mathrm{ppm}$ of As.

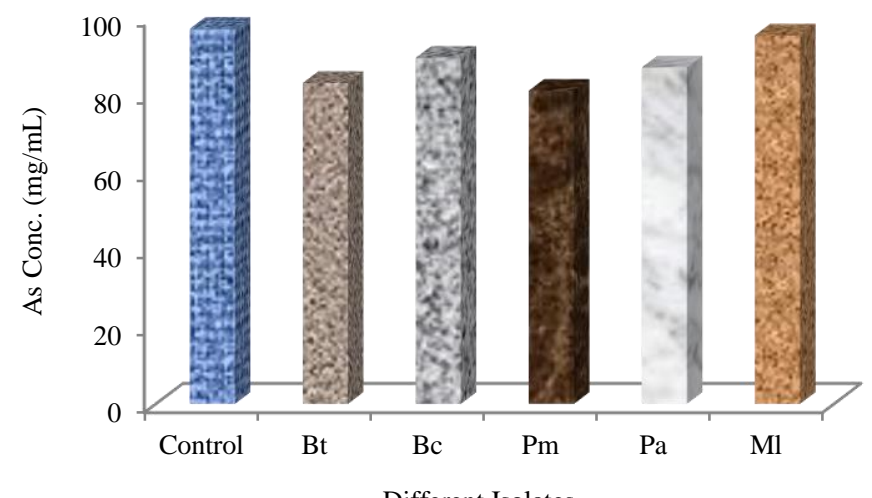

Different Isolates

Figure 7 (b): As for content after 48 hours incubation by different isolates

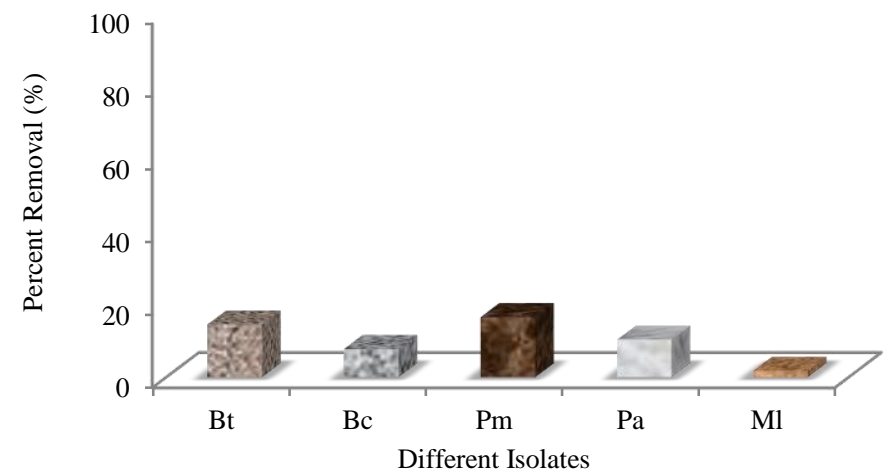

Figure 7 (c): Percent Removal of As content by each bacterial isolates 


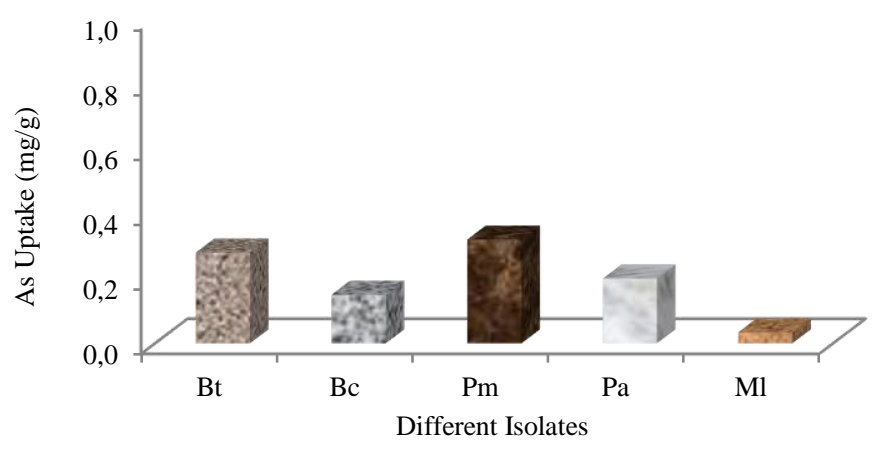

Figure 7 (d): Uptake of As content by each bacterial isolates

\section{DISCUSSION}

The preliminary aims of metal remediation are the removal of toxic metal elements from waste or mitigating the toxicity of metals from samples. A plethora of microbial-triggered reactions can fulfill these objectives through oxidationreduction reactions, metal methylations, and metal complexation (Kumar et al., 2010). Various types of microbial metabolic activities have long been manipulated for the welfare of human beings, such as in bioleaching to extract valuable metals from ores. The relationships between metals and microbes have contributed greatly to the progress of bioremediation (Malik, 2004; Bruins et al., 2000). Biosorption also called the removal of metal as a biological process that offers great advantages over traditional processes. It is easier to handle and more efficient, non-polluting, and can be incredibly selective; hence making it very cost-effective for treating huge volumes of wastewater with a low concentration of metals (Puranik and Pakniker, 1999).

Different microbes that are resistant to various metal molecules can grow and spread exponentially with the help of industrial wastes. The investigation of several metals-tolerant bacteria could be a useful method for simultaneously monitoring numerous harmful pollutants in an environmental sample. It is noted that both household and industrial wastes contribute to the resistance of bacteria that results in the threat to the environment and human health (Hossain and Anwar, 2012). Since all tested isolates showed significant tolerance against each heavy metal used (Islam et. al., 2020). Therefore, the bacterial species used in this experiment could be a better choice as a biosorption tool to treat effluents from industries that handle toxic heavy metals.In this experiment, the biosorption capacity of identified strains for $\mathrm{Cd}^{2+}$ ranged from $16.8 \%$ to $33.7 \%, \mathrm{Cr}^{6+}$ ranged from $23.96 \%$ to $39.58 \%, \mathrm{Ni}^{2+}$ ranged from $6.3 \%$ to $25.3 \%, \mathrm{Cu}^{2+}$ ranged from $7.61 \%$ to $30.43 \%, \mathrm{~Pb}^{2+}$ ranged from $18.95 \%$ to $40.95 \%$, and $\mathrm{As}^{5+}$ ranged from $1.75 \%$ to $16.49 \%$.

According to Nanda et al., (2011); Bacillus sp and Pseudomonas sp., were capable of reducing Cd from tannery effluent samples with an overall reduction of $44 \%$ and $56 \%$ respectively, after treatment. Pseudomonas $s p$. was proven to be capable of average reducing 34\% As, $\mathrm{Cu}$ was removed by both Bacillus sp. and Staphylococcus sp. with an average reduction of $62 \%$ and $34 \%$ respectively. Similar results were obtained in terms of Trametes versicolor for the removal of $\mathrm{Pb}^{2+}$ and $\mathrm{Cu}^{2+}$ (Bayramoglu et al., 2003), Bacillus sp. for chromium (Cr) removal (Wang et al., 1995), Bacillus firmus for lead $(\mathrm{Pb})$ and copper $(\mathrm{Cu})$ (Salehizadeh, 2003).

Pseudomonas sp. removed the heavy metals of $\mathrm{Co}$, As and $\mathrm{Cd}$, while Bacillus sp. Removed the heavy metals $\mathrm{Hg}$ and $\mathrm{Cu}$. According to Nanda et al., (2011), the average Cd removal was 56\% with average As removal by $34 \%$, and average Co removal was reported as 53\% by Pseudomonas sp. On average, $45 \%$ of mercury $(\mathrm{Hg})$ and $62 \%$ of Copper $(\mathrm{Cu})$ were reduced by Bacillus sp.

Several parameters influenced the biosorption ability of Klebsiella pneumonia that including the contact period, the initial lead concentration, the $\mathrm{pH}$ of the lead solution, and the amount of lead used (AL-Garni, 2005).

\section{CONCLUSION}

Heavy metal biosorption by different microbial biomass has become a crucial option for the removal of heavy metals.In the present study, five microbial strains Bacillus thuringiensis, Bacillus cereus, Pseudomonas monteilii, Pseudomonas aeruginosa, and Micrococcus luteus were screened for biosorption study. After treatment processes, Pseudomonas aeruginosa reduced the highest amount of $\mathrm{Pb}$ was $0.68 \mathrm{mg} / \mathrm{g}(41 \%)$, Bacillus thuringiensis also reduced the huge amount of $\mathrm{Cr}$ to $0.74 \mathrm{mg} / \mathrm{g}(39 \%)$ respectively. The result showed that the highest degradation of $\mathrm{Ni}$ and $\mathrm{Cu}$ were shown by Bacillus cereus $0.48 \mathrm{mg} / \mathrm{g}(25 \%)$ and Micrococcus luteusthat was around $0.56 \mathrm{mg} / \mathrm{g}(30 \%)$ and moderate degradation of Cd was shown by Pseudomonas monteilii that was around $0.46 \mathrm{mg} / \mathrm{g}(24 \%)$. The entire bacterial strains uptake a relatively lowest amount of As that range from $0.03-0.32 \mathrm{mg} / \mathrm{g}$ and percent removal was $2-16 \%$.

Acknowledgment: I would like to express my deepest gratitude to my honorable Mentors Dr. Mohammad Moniruzzaman, Principal Scientific Officer, Soil and Environment section, BCSIR, Dhaka for providing the facility of total metal analysis and finally grateful to Mr. BadhanShaha, Senior Scientific Officer, Soil and Environment section, BCSIR for his support and encouragement.

\section{REFERENCES}

Hoppe, M., \& Aggarwal, A. 2009. Special Economic Zones and Economic Diversification: Some Evidence from South Asia. In R. Newfarmer, W. Shaw, \& P. Walkenhorst (Eds.), Breaking into New Markets: Emerging Lessons for Export Diversification (pp. 211-222). Stanford University Press. http://www10.iadb.org/intal/intalcdi/PE/2009/03418.pdf

Ahalya, N., Ramachandra, T. V., Kanamadi, R. D., 2003. Biosorption of heavy metal. Res. J. Chem. Environ. 7(4): 71-78

Alam, M.S., Han, B., Mizan, A,.Pichtel, J. 2019. Assessment of soil and groundwater contamination at a former Tannery district in Dhaka, Bangladesh. Environ. Geochem. Health. 42(2): https://doi.org/10.1007/s10653-019-00457-6 Al-Garni SM. 2005. Biosorption of lead by Gram-ve capsulated and noncapsulated bacteria. Water SA. 31(3): 345-349, https://www.wrc.orc.za

Arias-Barreiro, C. R., Nishizaki, H., Okubo, K., Aoyama, I., \& Mori, I. C. 2010. Ecotoxicological characterization of tannery wastewater in Dhaka, Bangladesh. J Environ Biol, 31(4), 471-475

Aryal, M., Liakopoulou-Kyriakides, M., 2015. Bioremoval of heavy metals by bacterial biomass. Environ. Monit. Assess. 187(1): 4173.https://doi.org/10.1007/s10661-014-4173-z

Ayangbenro, A.S., and Babalola, O.O., 2017. A New Strategy for Heavy Metal Polluted Environments: A Review of Microbial Biosorbents. International Journal of Environmental Research and Public Health., 14(1):94 http://dx.doi.org/10.3390/ijerph14010094

Aziz, H.A., Adlan, M.N., Ariffin, KS,. 2015. Heavy metals (Cd, Pb, Zn, Ni, Cu and $\mathrm{Cr}(\mathrm{III})$ ) removal from water in Malaysia: post treatment by high quality $\begin{array}{llll}\text { limestone. } & \text { Bioresour. } & \text { Technol } & \text { 99(6):1578-1583 }\end{array}$ http://dx.doi.org/10.1016/j.biortech.2007.04.007

Barbieri, M. 2016. The importance of enrichment factor (EF) and geoaccumulation index (Igeo) to evaluate the soil contamination. J. Geol. Geophys. 5(1): 237 http://dx.doi.org/10.4172/2381-8719.1000237

Bayramoglu, G., Bekta, S., Arica, M.Y. 2003. Biosorption of heavy metal ions on immobilized white-rot fungus Trametes versicolor, J. Hazardous Materials. 101: 285-300

Bruins, M. R., Kapil, S., Oehme, F. W. 2000. Microbial resistance to metals in the environment. Ecotoxicol. Environ. Saf. 45(3): 198-207 http://dx.doi.org/ $\underline{10.1006 / \text { eesa. } 1999.1860}$

Flora, S.J.S., Mittal, M., Mehta, A. 2008. Heavy metal-induced oxidative stress and its reversal by chelation therapy. Ind. J. Med. Res. 128(4): 501-523.

Gadd, G.M., 2000. Bioremedial potential of microbial mechanisms of metal mobilization and immobilization. Curr. Opin. Biotechnol. 11 (3), 271-279 http://dx.doi.org/10.1016/s0958-1669(00)00095-1

Gain, P., Moral, S., Raj, P., Sircar, L. 2002. Bangladesh Environment: Facing the $21^{\text {st }}$ century. Society for Environment and Human Development (SEHD), Dhaka, Bangladesh.

Hietala, K. A.., and Roane, T. M. 2009. Microbial remediation of metals in Soils. 17. 201-220 http://dx.doi.org/10.1007/978-3-540-89621-0_11

Hossain, M., and Anwar, M.N. 2012. Isolation and Identification of Heavy Metal Tolerant Bacteria from Tannery Effluents. 29(1):23-26 https://doi.org/10.3329/bjm.v29i1.28430

Hussein, H., Farag, S., and Moawad, H. 2004. Isolation and characterization of Pseudomonas resistant to heavy metals contaminants. Arab J. Biotech. 7(1): 13-22 http://dx.doi.org/10.1021/bp00033a001

Igiri, B. E., OkoduwaS.I.R.,Idoko, G.O., Akabuogu, E.P., Adeyi, A.O and Ejiogu, I.K. 2018. Toxicity and Bioremediation of Heavy Metals Contaminated Ecosystem from Tannery Wastewater: A Review. Journal of Toxicology. https://doi.org/10.1155/2018/2568038

Islam, M. M., Das, P., Islam, M. M., Ahmed, S. R., Hossain, M. L., Kabir, M. H., \& Mamun, A. N. K. 2020. Heavy metal tolerant bacteria isolated and detected from 
the effluent of Hazaribagh tannery industry in Dhaka city. Bacterial Empire. 3(3): 14-19 http://dx.doi.org/10.36547/be.2020.3.3.14-19

Jan, A.T., Ali, A., Haq, Q.M.R., 2011. Glutathione as an antioxidant in inorganic mercury induced nephrotoxicity. J. Postgrad. Med. 2011, 57(1): 72-77 http://dx.doi.org/10.4103/0022-3859.74298

Jern, W.NG. 2006. Industrial wastewater treatment. Imperial College Press, 57 Shelton Street, Covent Garden, London WC2H 9HE, ISBN 1-86094-580-5

Joutey, N.T., Savel, H., Bahafid, W., Ghachtouli, N.EI. 2015. Mechanism of hexavalent chromium resistance and removal by microorganisms. Rev Environ ContamToxicol 233:45-69 http://dx.doi.org/10.1007/978-3-319-10479-9_2

Kar, R. N., Sahoo, B. N. \&Sukla, C. B. 1992. Removal of heavy metals from pure water using sulphate-reducing bacteria (SRB). Pollut Res. 11, 1-13

Kongjao, S., Damronglerd, S., and Hunsom, M. 2008. Simultaneous removal of organic and inorganic pollutants in tannery wastewater using electro coagulation technique, Korean J. Chem. Eng, 25(4): 703-709 http://dx.doi.org/10.1007/s11814-008-0115-1

Kumar, A., Bisht,B.S., Jishi, B.D. 2010. Biosorption of Heavy Metals by four acclimated microbial species, Bacillus spp., Pseudomonas spp., staphylococcus spp., andAspergillusniger. J. BIOL. ENVIRON. SCI., 4(12), 97-108

Lee, C.S.L., Li, X., Zhang, G., Li, J., Ding, A. J. and Wang, T. 2007. 'Heavy Metals and $\mathrm{Pb}$ Isotopic Composition of Aerosols in Urban and Suburban Areas of Hong Kong and Guangzhou, South China Evidence of the Long-Range Transport of Air

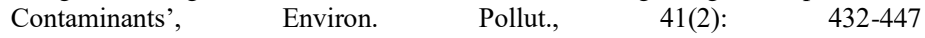
http://dx.doi.org/10.1016\%2Fj.atmosenv.2006.07.035

Lesmana, S,O., Febriana, N., Soetaredjo, F.E., Sunarso, J., and Ismadji, S. 2009. Studies on potential applications of biomass for the separation of heavy metals from water and wastewater," Biochemical Engineering Journal. 44(1):19-41 https://doi.org/10.1016/j.bej.2008.12.009

Li, Q., Cai, S., Mo, C., Chu, B., Peng, L., Yang, F., 2010. Toxic effects of heavy metals and their accumulation in vegetables grown in a saline soil. Ecotoxicol Environ Saf. 73 (1), 84-88 http://dx.doi.org/10.1016/j.ecoenv.2009.09.002

Malik, A. 2004. Metal bioremediation through growing cells. Environ Int., 30(2): 261-278 https://doi.org/10.1016/j.envint.2003.08.001

Malik, D.S. and Maurya P.K. 2014. Heavy metal concentration in water, sediment, and tissues of fish species (Heteropneustisfossilis and Puntiusticto) from Kali River, India," Toxicol Environ Chem, 96(8):1195-1206 https://doi.org/10.1080/02772248.2015.1015296

Mondal, N.C., Saxena, V.K., Singh, V.S. 2005. Impact of pollution due to tanneries on groundwater regime. Curr. Sci. 88(12): 1988-1994

Nanda, M., Sharma, D. and Kumar, A. 2011. Removal of Heavy Metals from Industrial Effluent Using Bacteria. Int .J. Environ. Sci. 2:765-780

Paul, H.L., Antunes, A.P.M., Covington, A.D., Evans, P., Phillips, P.S. 2013. Bangladeshi Leather Industry: An Overview of Recent Sustainable Developments. SLTC J. 97: 25-32 https://doi.org/10.1016/S0011-9164 (04)00193-6

Puranik, P. R., Pakniker, K. M. 1999. Biosorption of lead, cadmium and zinc by Citrobacterstrain MCM B-181: Characterization studies. Biotechnol. Prog. 15(2): 228-237 http://dx.doi.org/10.1021/bp990002r

Robin, R., Muduli, P., Vardhan, K., Ganguly, D., Abhilash, K., 2012. Heavy metal contamination and risk assessment in the marine environment of Arabian Sea, along the southwest coast of India. Am. J. chem. 2(4): 191-208. http://dx.doi.org/10.5923/j.chemistry.20120204.03

Salehizadeh, H., and Shojaosadati, S. A. 2003. Removal of metal ions from aqueous solution by polysaccharide produced from Bacillus firmus, Water Res.37(17):4231-4235 http://dx.doi.org/10.1016/S0043-1354(03)00418-4

Sekhar, K.C., Kamala, C.T., Chary, N.S., Sastry, A.R., Rao, T.N., Viramani, M. 2004. Removal of lead from aqueous solution using an immobilized biomaterial derived from plant biomass. J. Hazard. Mater. 108(1-2), 111-117 http://dx.doi.org/ 10.1016/j.jhazmat.2004.01.013

Volesky, B and Holan, Z.R,. 1995. Biosorption of heavy metals," Biotechnology Progress. 11(3):235-250

Volesky, B. 2007. Biosorption and me. Water Research. 41(18): 4017-4029 https://doi.org/10.1016/j.watres.2007.05.062

Wang, Y.T., Xiao, C. 1995. Factors affecting hexavalent chromium reduction in pure cultures of bacteria, Water Res. 29(11): 2467-2474 https://doi.org/10.1016/0043-1354(95)00093-Z

Zahid, A., Balke, K.D., Hassan, M.Q., Flegr, M. 2006. Evaluation of aquifer environment under Hazaribagh leather processing zone of Dhaka city. Environ. Geol. 50: 495-504 https://doi.org/10.1007/s00254-006-0225-1 